\title{
Opportunities and Challenges for the Badan Pertanahan Nasional (BPN) in Handling Land Cases in the New Normal Era
}

\author{
Rahmat Ramadhani ${ }^{*}$, Ummi Salamah Lubis ${ }^{2}$
}

\footnotetext{
1,2 Faculty of Law, Univesity of Muhmamadiyah Sumatera Utara, Medan, North Sumatera, 20238, Indonesia

* Corresponding author: rahmatramadhani@umsu.ac.id
}

\begin{tabular}{|c|c|}
\hline Article & Abstract \\
\hline $\begin{array}{l}\text { Article History } \\
\text { Received: Oct 19, 2020; } \\
\text { Reviewed: Nov 17, 2020; } \\
\text { Accepted: Jan 1, 2021; } \\
\text { Published: Jan 14, } 2021 .\end{array}$ & $\begin{array}{l}\text { During the Covid-19 pandemic and the new normal era, it became a separate } \\
\text { challenge in resolving land cases by the National Land Agency (BPN). This } \\
\text { condition is an opportunity as well as a challenge for the Ministry of } \\
\text { ATR/BPN in carrying out its duties as an authorized official in its field. This } \\
\text { writing uses legal research methods according to normative law. This type of } \\
\text { research used in this writing is library research. Based on the results of the } \\
\text { research, it is known that the settlement of land cases by the BPN is currently } \\
\text { carried out based on Regulation Number } 11 \text { of } 2016 \text { as an effort to guarantee } \\
\text { legal certainty and justice related to control, ownership and use of land. One of } \\
\text { the steps taken was mediation to reach an agreement, a peace agreement based on } \\
\text { current events made mediation mandatory for the parties. That the opportunities } \\
\text { and challenges for the BPNin resolving land disputes in accordance with the } \\
\text { objectives of the new standard will be changed by the BPN. For this reason, it is } \\
\text { necessary to conduct an assessment of opportunities and challenges for them. The } \\
\text { Ministry of ATR/ BPN in solving and handling land cases in the new normal } \\
\text { era like now. }\end{array}$ \\
\hline \multicolumn{2}{|c|}{$\begin{array}{l}\text { (C2021; This is an Open Acces Research distributed under the term of the Creative Commons } \\
\text { Attribution Licencee (https://Creativecommons.org/licences/by/4.0), which permits unrestricted } \\
\text { use, distribution, and reproduction in any medium, provided the original works is properly cited. }\end{array}$} \\
\hline
\end{tabular}




\section{INTRODUCTION}

The land issue is a problem that has occurred and has been in Indonesia for a long time (Pramana, Gede Aris Eka, Made Arjaya, \& Ida Ayu Putu Widiati, 2020). Data on disputes, conflicts and land cases that have been released by the National Land Agency states that up to September 2013, the number of land cases reached 4,223, consisting of the remaining cases in 2012 of 1,888 cases and new cases. 2,335 cases. The number of cases that had been resolved reached 2,014 cases or $47.69 \%$, which were spread across 33 provinces throughout Indonesia. The causes include; tenure of land without rights, boundary disputes, inheritance disputes, multiple sale, double certificates, replacement certificates, fake sale and purchase certificates, wrong designation of boundaries, overlapping, court decisions that lead to rejection (Ramadhani, 2019).

Much has happened in the community regarding disputed land.Disputed land often occurs because the land has economic value as well as spiritual value for the owner, besides being a source of life and livelihood for the community (Anggraeny, 2020). Issues related to agrarian resources are a sector that clearly shows tensions in the midst of society. There have been a number of major problems facing the aviss related to the government and the private sector involved in the fields of resources, agriculture(Zakie, 2017). The urgency of land management and use in order to create legal certainty for the community. The problem then arises because the early independence period was a disproportionate system of land ownership. To solve this problem, the government passed Law no. 5 in 1960 (Tristanto, 2019).

According to Mudjiono, there are several factors that cause land disputes. First, incomplete regulations; second, regulatory inconsistencies; third, land officials are less responsive to the needs and the amount of available land; fourth, inaccurate and incomplete data; fifth, wrong land data; sixth, limited human resources who are tasked with resolving land disputes; obnoxious, wrong land transactions; and in the end, there is a settlement from other agencies, so that overlapping authority occurs

Along with the development of numbersthe population until now, demands that someone needs land as land to live in and land to work for their lives(Gayo, 2018). Humans cannot be separated from the need for the importance of the function of the land. Many human activities depend on the land. Therefore, management and use really need to be regulated as well as possible to ensure legal certainty for the community (Hidayah, Wiryani, \& Madyasti, 2018; Tristanto, 2019). The need for land use often encounters legal problems (Jade, Putri, Al-fatih, Hukum, \& Muhammadiyah, 2020). The availability of a limited amount of land is inversely proportional to the number of population explosions. This condition is considered to be one of the factors triggering the skyrocketing number of disputes, conflicts and land ownership cases in Indonesia(Ramadhani, 2019). 
Problem after problemappears in the land sector, indicating that legal arrangements for the existence, use and designation of land are very urgent to be implemented including efforts for legal reform in the land sector so that legal certainty can be obtained for both land owners and other parties who utilize the land in its implementation(W, Atie Olii, \& Londa, 2018).

In order to create legal certainty for land rights, a strong legal foundation is needed(Ramadhani, 2017). However, land regulations and dispute resolution or land cases in Indonesia are still deemed unclear to provide legal certainty for the Indonesian people, especially during the Covid-19 pandemic and the new normal era, so it is necessary to refine regulations related to land case resolution which includes several basic principles. arrangements for handling and settlement of land cases("Kementerian ATR sempurnakan regulasi kasus pertanahan dan normal baru ANTARA News," n.d.).

In addition, matters that need serious attention are the implementation of mediation in the context of handling land cases by the Ministry AgrariadanTataRuang/BadanPertanahanNasional (Ministry of ATR/BPN) during the new normal period like now. Besides having to pay attention to health protocols, the implementation of mediation must also be in accordance with a Circular of Ministerial Pendayagunaan AparaturS ipil Negara dan Reformasi BirokrasiNumber 58 of 2020 concerningtheWork System of State CivilServants in the New Normal Order.This condition is an opportunity as well as a challenge for Ministry of ATR/BPN in carrying out their duties as an authorized official in their field. For that it is necessary to conduct an assessment of the opportunities and challenges for themMinistry of ATR/BPN in the settlement and handling of land cases in the new normal era like now.

The contribution of this research is in the form of a contribution of thought in an effort to improve Ministerial Regulation Number 11 of 2016 concerning Settlement of Land Cases as well as answering opportunities and challenges for the Ministry of ATR/BPN in the context of handling land cases in the new normal era.

\section{METHOD}

This research is a normative study through the formulation of legal principles, both from social data and from written positive legal data, formulating legal definitions(Asikin, 2013). The analysis is carried out by examining theories, concepts, legal principles, examining the systematics of statutory regulations, research on the level of synchronization of statutory regulations, examining comparative laws and legal history(Soekanto, 2005). The data used are secondary data using primary legal materials, secondary legal materials, and tertiary legal materials, in the form of; books, documents and regulations as well as references and related to the handling and settlement of land cases carried out by the Ministry of ATR/BPN. The approach taken in this research is a statutory approach (Peter Mahmud Marzuki, 2017). 


\section{RESULTS AND DISCUSSION}

1. Handling of Land Cases Based on Ministerial Regulation Number 11 of 2016 concerning Settlement of Land Cases

The trend of land cases has changed from time to time in accordance with the phenomenon of the problems found(Sakti, 2019).Land cases in the form of disputes, conflicts and land cases that arise in the midst of society are a result of circumstances/situations and conditions of rights and obligations as well as prohibitions that occur there is no proper fault with any land rights held/owned by a subject the subject of rights(Ramadhani, 2020).

Quoting the data described by Kurniati \& Fakhriahional, it is stated that:

"Several civil cases related to land received by the Supreme Court in 2010 reached 4,444, and this figure reached $6.26 \%$ of cases received in 2009 or 3,900 cases, then of 4,144 civil cases received, the largest number $(1,824$ cases or $44,26 \%)$ is a land dispute problem, so that in general the land has become the object of conflict which in the end cannot be utilized optimally, and is not economically beneficial for the rights of the community in general and does not fulfill social functions".(Kurniati \& Fakhriah, 2017).

Settlement of land disputes and disputes which are civil cases, the Court has settled it under a ruling usingHerzienInlandschReglement (HIR) as one of the sources of civil procedural law for Java and Madura in the Dutch East Indies. Then Rechtreglementvoor de Buitengewesten $(\mathrm{RBg})$ as civil procedural law for areas outside Java and Madura. Meanwhile, friendly dispute resolution using an alternative settlement mechanism for land dispute resolution uses a dispute resolution mechanism based on Law Number 30 of 1999 concerning Arbitration and Alternative Dispute Resolution(Kurniati \& Fakhriah, 2017).

For the settlement of land disputes and disputes of a civil nature, the implementation of land settlement can be carried out by the BadanPertanahanNasional (BPN) (Orlando, 2017). The object of the dispute which becomes the authority of the BadanPertanahanNasional (BPN) as referred to in Article 11 paragraph (3), Ministerial Regulation Number 11 of 2016 concerning Settlement of Land Cases. In this case the employer objected to the same rights, two (or more) different people. The resolution of disputes from the BadanPertanahanNasional (BPN) based on Ministerial Regulation Number 11 of 2016 concerning Settlement of Land Cases focuses on legal certainty and justice in terms of exploitation, ownership, use and use of land (Hajati, Sekarmadji, \& Winarsi, 2014). To achieve this goal, this Regulation has committed to the settlement of land disputes through mediation, namely the settlement of disputes based on the principle of deliberation to reach consensus for the good of all parties. As for mediation to reach an agreement, a peace agreement based on the news of the incident to make 
mediation binding on the parties is settled on the basis of a decision using HIR(Kurniati \& Fakhriah, 2017).

The terms 'Conflict' and 'Strife' have become a common conversation in human social life. This term is often used in everyday life in interactions. Scholars have different views about the meaning of conflict and disagreement. The definition of conflict and dispute includes the notion of the difference in interests between two or more parties; however, between conflict and dispute the two can be distinguished. In a conflict, there are situations where two or more parties face different interests; this will not develop into a dispute when the parties feel disadvantaged. only feeling dissatisfied or concerned, the conflict will develop into a dispute when the parties who feel aggrieved have expressed their dissatisfaction or concern, either directly to the party considered the cause of loss or other parties, all parties can resolve the conflict properly, then it will a dispute arises, but if the opposite happens, the parties cannot agree on a resolution of the conflict. the problem then a dispute will arise(Kurniati \& Fakhriah, 2017).

Disputes start on earth, starting with complaints from one of the parties (individuals or legal entities) that contain objections and claims for land rights regarding the status of land, priorities and assets on earth. The expectations of income adjustments by the administration in accordance with applicable legal provisions. Land disputes, this will ultimately lead to claims that someonehas more rights than others (priority) over land disputes. From a conflict approach perspective, the term land dispute is classified as open conflict and conflict that arises. In a dispute, the parties have identified, handled directly an ongoing or long-standing dispute and have not achieved satisfactory results for both parties (deadlock). In contrast to the conception stated above, in the perspective of Ministerial Regulation Number 11 of 2016 concerning Settlement of Land Cases, it is formulated independently of the definition and meaning to distinguish several terms in land cases which distinguish dispute, conflict and causes of land. -land between individuals, legal entities or institutions that have no major impact, while land disputes are land disputes between people, groups, classes. itself, an organization, legal entity, or institution that is trending or already having a huge impact. The following case Bumi is a land of dispute manipulation and judicial settlement(Kurniati \& Fakhriah, 2017).

Based on Regulation Number 11 of 2016 concerning Settlement of Land Affairs in Article 1 point 1, it is stated that a land case is a dispute, conflict or causes land to be settled in accordance with the provisions of land regulations and/orpolicies. In addition, item 2 states that land disputes, hereinafter referred to as disputes, are land disputes between individuals, legal entities, or institutions that have no major impact. Whereas Article 3 defines land conflicts as land disputes between 
people, groups, groups, organizations, legal entities, or institutions that have a tendency or have had a major impact.

Land settlement in Ministerial Regulation Number 11 of 2016 concerning Settlement of Land Cases which explains the purpose, purpose and scope of case resolution is to find out the history and root causes of disputes, conflicts or cases, formulate strategic policies for the settlement of any disputes, conflicts or disputes, resolve any disputes, conflicts or business so that land can be controlled, owned, used and operated by their owners. Land Affairs Settlement aims to provide legal certainty and justice related to control, ownership, use and use of land.

It is further stated in article 4 of Ministerial Regulation Number 11 of 2016 concerning Settlement of Land Cases that the resolution of disputes and conflicts is carried out on the initiative of the ministry or public complaints. Article 5 paragraph (1) to (4) of Regulation Number 11 of 2016 describes the initiative of the Ministry as follows, In implementing Dispute and Conflict Resolution, based on the Ministry's initiative as referred to in Article 4 letter a, the Ministry shall supervise the discovery of Wars and Conflicts that occur. (2) In a certain area, verification as referred to in paragraph (1) shall be carried out by being regulated by the Headquarters of the Land Agency, the Head of the Badan Pertanahan Nasional (BPN) or the General Management of complaints or reports in newspapers regarding Conflicts and Disputes, the Headquarters of state agencies to report the results of the supervision as referred to. in paragraph (2) to the office of the Provincial Badan Pertanahan Nasional (BPN) every 4 (four) months and this can be done to the Minister. In the event that the monitoring results need to be followed up, the Minister or the Provincial Badan Pertanahan Nasional (BPN) can contact the Central Land Office in dispute and Conflict resolution activities.

Meanwhile, dispute and conflict resolution is based on public complaints as referred to in Article 6 paragraph (1) to (6) of Regulation No. 11 of 2016, In implementing Dispute or Conflict resolution based on Complaints from the public as referred to in Article 4 letter b, the Ministry receives Dispute and Conflict Complaints from the public, Complaints, as referred to in paragraph (1), are submitted to the bureau of the national head office in writing, via a letter of complaint, mailbox, or the Ministry's website. In the event that the complaint as referred to in number 2 is submitted to the Provincial Badan Pertanahan Nasional (BPN)Bureau and/ortheMinistry, thecomplaintfile is forwarded to the Head Office of the Land Agency. Complaints as referred to in sentence (2) are very few download the identity of the reporter and the outline of the case. Complaints as referred to in paragraph 2 must be accompanied by a photocopier, the identity of the reporter, a photocopy of the identity of the assets and assets of the recipient when authorized, as well as supporting data for the complaint or providing evidence. The complaint as 
referred to in paragraph (2) shall be made according to the format listed in Attachment I which cannot be viewed separately from the Ministerial regulation.

The position of the BadanPertanahanNasional (BPN) as the only institution or institution that is authorized to carry out the mandate of land management has usually been recognized through Presidential Regulation (Perpres) Number 85 of 2009 amendments to Regulation No. 10 of 2006 concerning the BadanPertanahanNasional (BPN). In Article 2 of Presidential Decree Number 85 of 2009 Amendment to Presidential Regulation Number 10 of 2006 concerning the BadanPertanahanNasional (BPN), the BadanPertanahanNasional (BPN) states that the implementation of government tasks in the land sector is national, regional and sectorial. Presidential Decree Number 85 of 2009 amending Presidential Decree Number 10 of 2006 concerning the BadanPertanahanNasional (BPN), according to which the BadanPertanahanNasional (BPN) has a function; Assessment and handling of problems, disputes, disputes and conflicts in the land sector. With the premise that dispute resolution through mediation must be popularized, especially for land dispute resolution. Because it can be used, the functions and functions of the BadanPertanahanNasional (BPN) can include dispute resolution through mediation, as regulated in a regulation of the Minister of Agriculture and Administration. room/head of the National Land Office of the Republic of Indonesia number 11 of 2016(Meidiasari Amalia Nur Handini, 2018).

The use of applications that were in normal conditions can continue to function as a preventive measure so as not to be exposed to the Covid-19 virus. However, in new normal conditions, land settlement case activities are carried out face-to-face, while maintaining health order by providing ways to wash hands with soap at the National Land Agency (BPN) office, check body temperature, must wear masks, and also provide hand sanitizer. As is the case in various government offices in Indonesia, if there are employees who are affected by the Covid-19 virus there, even though previously it was only normal to apply the work mechanism at home. Only a few employees carry out the work, and work is carried out alternately with other employees. Currently, it is working as usual, but still following health protocols. Thus, the procession of land management under normal conditions has just proceeded as before. In addition, it is important to note that the impact of developments in information technology facilitates the dispute resolution process, because case documents can be transmitted more quickly (Faisal Riza, 2019).

\section{Opportunities and Challenges for the Badan Pertanahan Nasional (BPN) in Handling Land Cases in the New Normal Era}

The challenge for the Badan Pertanahan Nasional (BPN) in handling land cases in the new normal era lies in limiting the movement of workers who cannot work freely as before in order to prevent the spread of Covid-19 in 
Indonesia("Kementerian ATR sempurnakan regulasi kasus pertanahan dan normal baru - ANTARA News," n.d.). One of the systems used for handling land cases is mediation, where mediation is one way to obtain legal protection. Legal protection is one of the constitutional rights of citizens which must be distributed by the Stateto every member of society. This is in accordance with the provisions of Article $28 \mathrm{D}$ paragraph (1) of the 1945 Constitution of the Republic of Indonesia which states that everyone has the right to recognition, guarantees, protection and legal certainty that is just as well as equal treatment in law(Fajaruddin, 2020).

A challenge for the Badan Pertanahan Nasional (BPN) considering the new normal conditions that require employees to work with limited numbers and other things in accordance with the Circular of Ministerial PendayagunaanAparaturSipil Negara danReformasiBirokrasiNumber 58 of 2020 concerningtheWork System of State CivilServants in the New Normal Order.

Based on the Circular of the Minister of State Apparatus Empowerment and Bureaucratic Reform Number 582020 concerning Civil Service Work Procedures in the framework of the new normal apart from maintaining sustainability. Starting from the implementation of duties and functions in the field of government and public services to promoting the health and safety of employees in a new normal order by implementing health protocols in their daily activities. Adaptation to the new productive and safe Covid-19 normal order in Ministries/Institutions/Regions includes adjustments to the work system, supporting human resources, supporting infrastructure by paying attention to the Health Protocol.

Based on the Circular of the Minister of Administrative and Bureaucratic Reform No. 582020 concerning the Work Procedure for Civil Servants in the framework of the new normal to ensure the smooth operation of the Ministry /Institution/Regional Personnel, in this case the Badan Pertanahan Nasional (BPN) in implementing provisions To simplify business processes and standard operating procedures by using information and communication technology, in the form of use information media to deliver new service standards through publication media, open online communication media as a forum for consultation as well as complaints (public complaints are one of the two bases for Badan Pertanahan Nasional (BPN) to conduct dispute resolution reservations), ensure that service product outputs are carried out online and offline which are determined according to standards determined, pay attention to safe distance (physical distance), health and safety at work. employees who provide direct offline services according to health protocols established by the Ministryof Health.

Moreover, in applying new standards, the supporting infrastructure as it is today must also be taken into account. Based on the circular of the Minister for Administrative Reform and Bureaucratic Reform No. 582020 concerning the work procedure of the state civil apparatus in the framework of the new normal in 
adjusting the work system for the state civil apparatus in the new normal productive and safe Covid-19 order, supervisors for staff officers in ministries/institutions/regionstoprovidethenecessary supporting facilities and infrastructure for the apparatus civil society in the implementation of official duties with the flexibility of work locations, which include the optimization of the use of information technology and other office infrastructure, in accordance with the budget availability of each public authority. Ensuring that the application of information technology in government administration, public services is carried out with a focus on guidelines for the use of information and communication technology, as well as information security and cybersecurity; and adjusting the work environment to prevent and control the spread of Covid-19 in accordance with the guidelines of the Minister of Health Decree HK.01.07/MENKES/328/2020 for office and industrial workplaces to support business continuity in a pandemic situation.

Based on the description above, it can be seen that for employees who will carry out their duties to resolve land dispute cases who must face-to-face (offline), they must still observe health protocols in accordance with the direction of the Minister of Health. Then the Badan Pertanahan Nasional (BPN) is expected to open opportunities to create an online forum to accommodate public complaints related to land disputes. Disputes are part of human life as social beings. Interaction between humans allows a problem to arise, if the parties can solve the problem by themselves, then disputes will not occur. Conversely, if the parties cannot reach an agreement on a solution to solve the problem, then disputes will arise. In principle, humans will always look for the best way to resolve disputes for the continuation of their lives, but over time the problems that occur become more and more complex and complicated, so dispute resolution has developed(Zulaeha, 2016).

Civil dispute resolution can be broadly divided into two ways, namely litigation dispute resolution (judicial) and non-controversial dispute resolution (outside the law). Each community has a way of reaching an agreement to determine dispute resolution options. Dispute resolution methods will have consequences, both for the disputing parties and the wider community.Therefore there are consequences in choosing dispute resolution, so choosing the most suitable mechanism for the parties must pay attention to the form of the problem and what the parties expect in dispute resolution as well as the costs that may be incurred. or initially assumed by the parties. There are several models of dispute resolution outside the court, such as negotiation, mediation, and arbitration. With the increase in the number of cases that go to court, mediation has received a lot of attention to help resolve the problem of case accumulation in court (Zulaeha, 2016).

Mediation is a concept which is a suitable concept by the Supreme Court to implement peace process in civil cases regulated by article $130 \mathrm{HIR} / 154 \mathrm{Rbg}$. This 
view stems from the assumption that the peace process using the concept of mediation will provide more optimal results than the peace process by providing opportunities for parties to carry out peace on their own. The presence of mediators in the peace process ultimately aims to provide a faster, simpler and cheaper dispute resolution solution as stipulated in article 2 paragraph (4) of Law No. 48 of 2009 concerning Judicial Power(Ridho, 2020). Mediation dispute resolution in particular and out-of-court dispute resolution is generally limited to civil disputes, such as property rights disputes, disputes regarding inheritance rights, and others (Idris, 2013).

Mediation is a process of negotiating problem solving in which an outside, impartial, neutral party does not work with the disputing parties to assist them in reaching an agreement on a satisfactory negotiation result. Unlike judges and arbitrators, the mediator has the power to decide disputes between the parties, instead the parties authorize the mediator to help them resolve problems between them.

Mediation is a negotiation process that is assisted by a third party. This results in the parties unable to resolve the dispute by themselves using a neutral third party service to help them reach an agreement. The presence of a third party (mediator) in mediation is not like a third party (judge) in a judicial process who applies the law to existing facts to achieve a result (Zulaeha, 2016).

It appears that all disputes, and questions should be handled in a clearly defined step-by-step manner to arrive at the settlement of court decisions so that the stages can be measured. Furthermore, the settlement must be based on the fact that the law is valid and solid/binding, and that the rights of the complainant or complainant are protected all these rights can be proven legally, physically and administratively("Kementerian ATR sempurnakan regulasi kasus pertanahan dan normal baru - ANTARA News," n.d.).

Rules regarding the settlement of land problems summarized in the field; namely, receiving and disseminating complaints, handling and resolving disputes and conflicts, handling cases and; implementation of judicial decisions; cancellation; Ministry of Justice products, mediation, handling and settlement of cases by; information about; case development and resolution, monitoring; evaluation and reporting, administrative sanctions and legal protection. In response to this, the Minister of Agrarian Affairs and Spatial Planning/Head of the BadanPertanahanNasional (BPN) underlined the scope of the mediation which was considered very good and beneficial for the company and the ranks of the Department of Agraia and Layout/BadanPertanahanNasional (BPN) ("Kementerian ATR sempurnakan regulasi kasus pertanahan dan normal baru - ANTARA News," n.d.). 
Mediation is one of the systems that the Ministry of Agrarian and Spatial Administration/Badan Pertanahan Nasional (BPN)wantsto strengthen in the amendment to Regulation Number 11 of 2016 concerning Settlement of Land Cases in the new normal era. For this reason, it is deemed necessary to discuss mediation according to Regulation Number 11 of 2016 concerning Settlement of Land Cases.

The rule of law in Indonesia in a broader concept, namely the rule of law, where the government's duties are not limited to such a concept in the 19th century.In the modern sense asking the government to create social welfare. In this case, the government does not only have the authority, duty and responsibility to maintain security and order, but a broader responsibility, namely welfare and social justice for all its people. In this context, it can be assumed that the government also regulates the handling of legal issues in the land sector to meet the needs of people who face land problems. With the issuance of Regulation Number 11 of 2016, mediation is used as a land dispute settlement mechanism by the BadanPertanahanNasional (BPN). In Regulation Number 11 of 2016, the basis for settlement is differentiated based on the arrival of the report(Kurniati \& Fakhriah, 2017).

If there are disputes and conflicts, the authorized department or agency, the officer in charge of a dispute, is the dispute, conflict and the case is reported in the report and analysis results to the head office. soil. Although the terms disputes and conflicts do not convey the authority of the BadanPertanahanNasional (BPN) and the authority of other agencies, the officials responsible for litigation, litigation and cases transfer a written explanation to. Dispute resolution and dispute resolution to whistleblowers, however, the BadanPertanahanNasional (BPN) can take the initiative to carry out disputes or dispute resolution through mediation. In the case of disputes, mediapimediapimediapimediapimediapimediapimediaki is carried out on the basis of deliberation to reach a consensus to get inspiration from the parties. In the provisions of Article 37 (2) one of the parties refuses to mediate if a settlement is submitted to the parties in accordance with the provisions of laws and regulations. As referred to in Article 39 paragraph (3) and paragraph (4), if one of the objecting parties cannot attend the mediation, the implementation can be postponed to allow all parties to attend. If 3 (3) times the value invited, the participant does not attend the mediation, the mediation is null and void and the parties are willing to resolve any dispute or conflict in accordance with the provisions of the legislation(Kurniati \& Fakhriah, 2017).

The provisions of Article 38 (1) and (2) stipulate that the mediation has been carried out within 30 (30) days, and the intermediary is from the Central BadanPertanahanNasional (BPN), the BadanPertanahanNasional (BPN) Regional Office and/or the city district land office as referred to in Article 39 paragraph 1. letter $\mathrm{C}$. With regard to mediation to reach an agreement, a peace agreement based 
on the event of a peace agreement must be registered with the Registrar of the District Court, so that it can be legally binding as referred to in Article 41 (1) and (2), and conflict resolution submits a land settlement report to the head. the regional office of the BadanPertanahanNasional (BPN) or the Minister. Minister for(Kurniati \& Fakhriah, 2017):

a. Decision to Cancel Land Rights;

b. Certificate Cancellation Decision;

c. Decision on Change of Data on Certificate, Measurement Letter, Land Book and / or other General Register; or

d. Notification that there is no administrative error. "The decision must be implemented unless there is a valid reason to delay its implementation.

One of the weaknesses of mediation is the implementation of decisions or agreements that have been obtained by the disputing parties. Basically, mediation is an agreement between the two disputing parties with a mediator as the mediator, but this cannot be avoided from the default by either party regarding the agreement that has been taken. For this reason, the legal certainty of mediation is still being questioned. This is a challenge that must be resolved by the Badan Pertanahan Nasional (BPN) in law enforcement against land dispute resolution in Indonesia during the new normal period.Even though in reality most of the cases that go to the District CourtIt cannot be reconciled with the negotiation effort, but that does not mean that this effort is carried out peacefully, but that is precisely what is a challenge for the mediator, especially the Judge, to be able to play his role as an accomplished mediator by maximally applying his abilities and skills in paving the way for the parties(Ridho, 2020).

In principle, land dispute settlement through mediation must achieve settlement efficiency and legal certainty, in order to avoid default by either party, the above results of the agreement reached by the parties can submit a peace agreement to the competent authority. to the arbiter to get a peace deed by filing a lawsuit. Then, stakeholder agreement can be strengthened in the form of peaceful action (acta van dading). With the peace deed, if one of the parties is negligent, execution can be requested in court(Hajati et al., 2014).

Apart from mediation, the Badan Pertanahan Nasional (BPN) is also expected to focus on ownership of rights over land rights. It is known that the Indonesian people have the custom of pawning their land to get the amount of money they need, the practice of selling pawns like this often results in losses for one of the parties implementing it, both the party who pawned the land and the pledge party. This is of course also a challenge for the Badan Pertanahan Nasional (BPN), because if any losses arise, there will be land disputes.

The complete systematic land registration program has also been hampered by the Covid-19 pandemic during this new normal period. This is also a challenge for the Badan Pertanahan Nasional (BPN) in its duties because a complete systematic land registration is a program that is considered to make it easier for the community. Complete systematic land registration is the activity of first-time land registration carried out simultaneously for all objects of land registration throughout the territory of the Republic of Indonesia in one village/sub-districtarea orothernames at the 
same level, which includes the collection and determination of the correctness of physical data and juridical data. regarding one or more land registration objects for the purpose of registration(Ayu, 2019).

Amendments to Regulation Number 11 of 2016 concerning Settlement of Land Cases, especially in the scope of mediation as a system for resolving land disputes or conflicts, can become an opportunity for the Badan Pertanahan Nasional (BPN) to provide legal certainty for people who are looking for it while at the same time carrying out their duties properly based on the orders of the prevailing laws .

Opportunities for the Badan Pertanahan Nasional (BPN) and the public who wish to obtain legal certainty over land cases can be guaranteed through the Circular of the Minister for Administrative Reform and Bureaucratic Reform Number 58 of 2020 concerning the Work System for State Civil Servants in the New Normal Order to ensure the smooth operation of the Ministry's public services/Institution/Region. Thus, under normal circumstances, it will not hinder both the Badan Pertanahan Nasional (BPN) and the community from resolving a land case.

The most crucial challenge for the BadanPertanahanNasional (BPN) and the community to resolve land cases in a new normal state is to open opportunities for an increase in positive cases of Covid-19, due to the large number of face-to-face processes to resolve land cases. Thus, the BadanPertanahanNasional (BPN) and the community must strictly adhere to health protocols in resolving land cases under new normal conditions. If the use of the Justisia application is still being empowered in a new normal state, there are obstacles in its implementation, one of which is during the process of measuring the land, the measuring should meet the land equivalent.

\section{CONCLUSION}

Settlement of disputes by the BadanPertanahanNasional (BPN) based on Regulation Number 11 of 2016 is to ensure legal certainty and justice related to control, ownership, use and use of land. To achieve this goal, Regulation Number 11 2016 regulates the settlement of land disputes through mediation, that resolution of disputes is based on the principle of deliberation to reach consensus for the good of all parties. In the case of mediation to reach an agreement, a Peace Agreement is drawn up based on the news of the mediation incident which binds the parties. Dispute and conflict resolution in Regulation Number 11 of 2016 is implemented based on the initiative of the Ministry and Public Complaints.

Employees who will carry out their duties to resolve land dispute cases that must face-to-face (offline) must still observe health protocols in accordance with the direction of the Minister of Health. Then the BadanPertanahanNasional (BPN) is expected to open the opportunity to create an online forum to accommodate public complaints related to land disputes. The opportunities and challenges of the BadanPertanahanNasional (BPN) in resolving land disputes in normal times are focused on several areas that will be changed by the BadanPertanahanNasional (BPN) from Regulation No. 112016 Mediation is one of the mechanisms that will be 
strengthened by the BadanPertanahanNasional (BPN) with the aim of obtaining legal certainty for parties bound by a mediation agreement so as not to arbitrarily default on the agreements that have been made.

\section{ACKNOWLEDGMENTS}

Thank and highest respect to the editor-in-chief and all administrators of Legality: Jurnal Ilmiah Hukum for publishing this journal. To my younger siblings; Taufik Hidayat Lubis., S.S., S.H., M.H., Ismail Koto, S.H., M.H., Cynthia Hadita, S.H., and Abdul Inal Fattah Tarigan, S.H, would like to express their deep gratitude for their contribution in completing the preparation of this scientific journal.

\section{REFERENCES}

Anggraeny, I. (2020). LEGAL REVIEW OF SELLING LAND OF

INHERITANCE WITHOUT APPROVAL OF ALL HEIRS. Legality :

Jurnal Ilmiah Hukum, 28(1), 107-120.

https://doi.org/10.22219/ljih.v28i1.11817

Asikin, A. dan Z. (2013). Pengantar Metode Penelitian Hukum. Jakarta: Rajawali Pers.

Ayu, I. K. (2019). Problematika Pelaksanaan Pendaftaran Tanah Melalui Pendaftaran Tanah Sistematis Lengkap Di Kota Batu. Jurnal Ilmiah Hukum LEGALITY, 27(1), 27. https://doi.org/10.22219/jihl.v27i1.8956

Faisal Riza, R. A. (2019). ALTERNATIF PENYELESAIAN SENGKETA SECARA ARBITRASE MELALUI PEMANFAATAN TEKNOLOGI INFORMASI. Delegalata: Jurnal Ilmu Hukum, 4(1), 77-86.

Fajaruddin, R. K. B. P. (2020). 'Aisyiyah's Legal Aid Model in Medan City. International Journal Reglement \& Society, 1(2), 38-43.

Gayo, A. A. (2018). PERLINDUNGAN HUKUM HAK ATAS TANAH ADAT (Studi Kasus di Provinsi Aceh khusunya Kabupaten Bener Meriah). Jurnal Penelitian Hukum Dejure, 18(3(101)), 77. https://doi.org/10.14258/izvasu(2018)3-13

Hajati, S., Sekarmadji, A., \& Winarsi, S. (2014). Model Penyelesaian Sengketa Pertanahan Melalui Mediasi Berkepastian Hukum. Jurnal Dinamika Hukum, 14(1), 36-48.

Hidayah, N. P., Wiryani, F., \& Madyasti, H. P. (2018). The Strengthening Legal Protection of Indigenous People in Facing Investment Climate in Era of Asean Economic Community in. In IOP Conference Series: Earth and Environmental Science (Vol. 175, pp. 1-5). https://doi.org/10.1088/17551315/175/1/012208

Jade, A. P., Putri, D. N., Al-fatih, S., Hukum, F., \& Muhammadiyah, U. (2020). PERIZINAN MEMBUKA TANAH NEGARA DI KOTA BALIKPAPAN. Supremasi Hukum: Jurnal Penelitian Hukum, 29(2), 102-130. https://doi.org/https://doi.org/10.33369/jsh.29.2.\%25p

Kementerian ATR sempurnakan regulasi kasus pertanahan dan normal baru ANTARA News. (n.d.).

Kurniati, N., \& Fakhriah, E. L. (2017). BPN SEBAGAI MEDIATOR DALAM PENYELESAIAN SENGKETA TANAH DI INDONESIA PASCA 
PERKABAN NO. 11 TAHUN 2016. Sosiohumaniora, 19(2), 95-105.

Meidiasari Amalia Nur Handini. (2018). Penyesaian Sengketa Tanah Melalui Mediasi (Studi Kasus di Kantor Pertanahan Kabupaten Sukoharjo). Surakarta.

Orlando, G. (2017). Kewenangan Badan Pertanahan Nasional Dalam Menangani Sengketa Pertanahan. Jurnal Notarius, 3(2), 49.

Peter Mahmud Marzuki. (2017). Penelitian Hukum: Edisi Revisi (Cetakan ke). Jakarta: Kencana.

Pramana, I., Gede Aris Eka, I., Made Arjaya, \& Ida Ayu Putu Widiati. (2020). Kompetensi Absolut Peradilan Tata Usaha Negara Terkait Titik Singgung Antara Peradilan Tata Usaha Negara dan Peradilan Umum dalam Sengketa Pertanahan. Jurnal Analogi Hukum, 2(1). https://doi.org/10.22225/.2.1.1604.27-31

Ramadhani, R. (2017). Jaminan Kepastian Hukum Yang Terkandung Dalam Sertipikat Hak Atas Tanah. De Lega Lata: Jurnal Imu Hukum, 2(1), 139157. https://doi.org/10.31219/osf.io/6tzes

Ramadhani, R. (2019). Dasar-Dasar Hukum Agraria. Medan: CV. Pustaka Prima. Ramadhani, R. (2020). Peran Poltik Terhadap Pembangunan Hukum Agraria Nasional. SOSEK: Jurnal Sosial \& Ekonomi, 1(1), 1-6.

Ridho, R. V. (2020). Penyelesaian Perdata Melalui Perdamaian (Putusan Nomor 305/Pdt.G/2015/PT.Mdn). Iuris Studia: Jurnal Kajian Hukum, 1(2), 133143.

Sakti, T. (2019). Penelitian Peningkatan Peran Mediator Dalam Kepastian Penyelesaian Sengketa Dan Konflik Pertanahan. https://doi.org/10.31227/osf.io/mw3f2

Soekanto, S. (2005). Pengantar Penelitian Hukum.

Tristanto, W. Y. (2019). Harmonisasi Regulasi Kepemilikan Tanah Pertanian Secara Absentee Bagi Pegawai Negeri Dalam Program Landreform. Jurnal Ilmiah Hukum LEGALITY, 26(2), 281. https://doi.org/10.22219/jihl.v26i2.7801

W, K. A. K., Atie Olii, \& Londa, J. E. (2018). PROSES PENYELESAIAN SENGKETA HAK ATAS TANAH MENURUT UU NO. 4 TAHUN 1996 TENTANG HAK TANGGUNGAN. Lex Privatum, VI(3), 121-128.

Zakie, M. (2017). Konflik Agraria Yang Tak Pernah Reda. Jurnal Ilmiah Hukum LEGALITY, 24(1), 40. https://doi.org/10.22219/jihl.v24i1.4256

Zulaeha, M. (2016). Mediasi Interest Based Dalam Penyelesaian Sengketa Tanah. KERTHA PATRIKA, 38(Januari-April), 156-166. 